\title{
Levels of Stewart's Wilt Resistance Necessary to Prevent Reductions in Yield of Sweet Corn Hybrids
}

\author{
Noah D. Freeman and Jerald K. Pataky, Department of Crop Sciences, University of Illinois, Urbana 61801
}

\begin{abstract}
Freeman, N. D., and Pataky, J. K. 2001. Levels of Stewart's wilt resistance necessary to prevent reductions in yield of sweet corn hybrids. Plant Dis. 85:1278-1284.

Stewart's wilt reactions and yield of a total of 69 sweet corn hybrids were evaluated in trials in 1999 and 2000 in order to determine the level of Stewart's wilt resistance necessary to prevent reduction in yield of sweet corn hybrids. Plants at the 2- to 3-leaf stage were inoculated with Erwinia stewartii using the pinprick method. Stewart's wilt symptoms were rated from 1 to 9, and incidence of systemic infection was determined as a percentage for each experimental unit. Primary ears were harvested about 21 days after midsilk, and yield was measured as ear weight and number of marketable ears. Percent yield was calculated for each hybrid by dividing yield from inoculated treatments by yield from noninoculated treatments and multiplying by 100 . Hybrid means for Stewart's wilt ratings in inoculated treatments ranged from 2.0 to 7.3. The relationships between percent yield and Stewart's wilt severity ratings were described best by curvilinear regressions, whereas percent yield decreased linearly with the incidence of systemic infection in 2000. Ear weights of hybrids with ratings below 3 or 3.5 were estimated from the regression equations to be within 95 or $92 \%$, respectively, of those from noninoculated treatments of the same hybrid. The number of marketable ears from hybrids with ratings of 3 or below was estimated from the regression equations to be within $90 \%$ of those from noninoculated treatments of the same hybrid. A level of resistance that resulted in Stewart's wilt ratings below 3 or 3.5 corresponded to nonsystemic infection of most plants (i.e., incidence of systemic infection below 5 or $10 \%$, respectively). The adverse effects of Stewart's wilt on ear weight and marketability appeared to be minor for sweet corn hybrids with levels of resistance that prevented or minimized systemic infection.
\end{abstract}

Stewart's bacterial wilt, caused by Erwinia stewartii (Syn. Pantoea stewartii), is an important disease of sweet corn that causes serious problems when susceptible hybrids are grown in the eastern and midwestern United States (16). The corn flea beetle, Chaetocnema pulicaria Melsheimer, introduces E. stewartii to plant tissues wounded during feeding (17). Movement of E. stewartii in the vascular system of resistant plants is restricted to within a few centimeters of flea beetle feeding wounds (3). The bacterium may move systemically throughout the vascular system of susceptible plants.

Resistance is the most efficient method to control Stewart's wilt. When Stewart's wilt was epidemic in the United States in the early 1930s, most sweet corn cultivars that were grown widely were more susceptible than dent corn cultivars $(7,8)$. Presently, several sweet corn hybrids have

Corresponding author: J. K. Pataky

E-mail: j-pataky@uiuc.edu

Partial funding provided by the Illinois Council on Food and Agricultural Research (CFAR) Grant No. 99I-016-3 and the Midwest Food Processors Association.

Accepted for publication 12 September 2001.

Publication no. D-2001-1026-01R

(๐) 2001 The American Phytopathological Society resistant or moderately resistant reactions to E. stewartii $(11,13,15)$, but susceptible or moderately susceptible hybrids are grown in some areas where the disease is endemic because these hybrids have superior horticultural and agronomic qualities, such as germination, seedling vigor, ear shape, kernel depth, and cut kernel weight.

The effects of Stewart's wilt on corn yield have been studied previously. Estimates of dent corn yield reductions due to Stewart's wilt ranged from 20 to $50 \%$ in the $1930 \mathrm{~s}$, but often these estimates were not based on experimental data $(6,7)$. More recently, Ayers et al. (1) reported that a susceptible sweet corn hybrid, Sugar and Gold, had only 3 to 15 ears per 50 plants when infected heavily with Stewart's wilt. Goth and Stienke (5) screened 22 sweet corn hybrids for reactions to Stewart's wilt and reported stand reductions of 40 to $90 \%$ and no marketable yield among susceptible hybrids. Stand reductions ranged from 10 to $40 \%$ and yields were reduced among tolerant hybrids. Stands were reduced by less than $10 \%$ and yield was affected negligibly among resistant hybrids. When Jacobsen et al. (9) evaluated 88 sweet corn varieties for reactions to Stewart's wilt, yield of varieties with less then $10 \%$ incidence was affected very little. Varieties with 10 to $30 \%$ incidence had slight yield losses. Yield of cultivars with greater than $30 \%$ incidence was reduced to unsatisfactory levels. Pataky et al. (13) observed yield reductions as high as $60 \%$ for susceptible sweet corn hybrids inoculated with $E$. stewartii about 3 to 5 weeks after planting. Yield reductions due to Stewart's wilt decreased substantially as levels of resistance increased. The relationship between yield and Stewart's wilt reactions was described by a quadratic relationship in two of three trials. Suparyono and Pataky (18) observed a damage threshold for susceptible and moderately susceptible sweet corn hybrids of approximately $40 \%$ severity, which corresponds to systemic infection associated with slight stunting 1 week before harvest. Beyond this threshold, sweet corn yield (ear weight or marketable ears) decreased about $18 \%$ for each $10 \%$ increase in severity. Stewart's wilt severity ranged from about 40 to $100 \%$ when the susceptible and moderately susceptible hybrids were inoculated at the three- to five-leaf stages. Severity ranged from about 20 to $60 \%$ when these hybrids were inoculated at the five- to seven-leaf stages.

In the past decade, several new sweet corn hybrids have been developed with moderate to high levels of resistance to Stewart's wilt (11). To develop these hybrids, inbred lines have been selected for resistance to Stewart's wilt and for a number of other traits that are important in sweet corn, such as yield, eating quality, ear and kernel characteristics, maturity, and resistance to other diseases. If moderate levels of Stewart's wilt resistance adequately prevent yield losses under most situations, additional emphasis can be placed during the development of inbred lines on other traits necessary for sweet corn to be acceptable for commercial production. The objective of this research was to determine the level of Stewart's wilt resistance necessary to prevent reduction in yield of sweet corn hybrids.

\section{MATERIALS AND METHODS}

Sweet corn hybrids were planted 11 May 1999 and 5 May 2000 at the University of Illinois South Farms, Urbana, IL. Standard production practices were followed. The treatment design was a factorial of hybrids and two treatments (inoculated or noninoculated). The experiment included 59 and 60 hybrids in 1999 and 2000, respectively. Fifty hybrids were common to both experiments. The experimental design was a split-plot of a randomized complete block with five replicates in 1999 and four replicates in 2000 . Hybrids were planted in main plots. Plants in subplots were inoculated with E. stewartii or they were not 
Table 1. Stewart's wilt severity ratings, incidence (\%) of systemically infected plants, and percent yield based on ear weight and marketable ears for sweet corn hybrids inoculated with Erwinia stewartii in 1999 and 2000

\begin{tabular}{|c|c|c|c|c|c|c|c|}
\hline \multirow[b]{3}{*}{ Hybrid } & \multirow{2}{*}{\multicolumn{2}{|c|}{ Stewart's rating ${ }^{\mathrm{a}}$}} & \multirow{3}{*}{$\begin{array}{c}\begin{array}{c}\text { Systemic }^{b} \\
\text { infection }(\%)\end{array} \\
2000\end{array}$} & \multicolumn{4}{|c|}{ Percent yield } \\
\hline & & & & \multicolumn{2}{|c|}{ Ear weight $^{\mathrm{c}}$} & \multicolumn{2}{|c|}{ Marketable ears $^{d}$} \\
\hline & 1999 & 2000 & & 1999 & 2000 & 1999 & 2000 \\
\hline$\overline{\mathrm{ACX}} 405$ & 5.0 & $\ldots^{\mathrm{e}}$ & 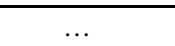 & 78 & $\ldots$ & 71 & $\ldots$ \\
\hline ACX 420 & 5.0 & $\ldots$ & $\ldots$ & 81 & $\ldots$ & 92 & $\ldots$ \\
\hline ACX 427 & 6.4 & $\ldots$ & $\ldots$ & 66 & $\ldots$ & 67 & $\ldots$ \\
\hline ACX 500 & $\ldots$ & 4.9 & 35 & $\ldots$ & 86 & $\ldots$ & $\ldots$ \\
\hline ACX 502 & $\ldots$ & 5.4 & 37 & $\ldots$ & 82 & $\ldots$ & 55 \\
\hline ACX 610 & $\ldots$ & 6.8 & 79 & $\ldots$ & 26 & $\ldots$ & 5 \\
\hline Ambrosia & 2.8 & 4.0 & 6 & 92 & 96 & 95 & 95 \\
\hline Beretta & 6.5 & 7.3 & 69 & 64 & 31 & 55 & 23 \\
\hline Bonanza & 3.4 & 5.2 & 39 & 95 & 89 & 88 & 79 \\
\hline Bonus & 2.4 & 2.0 & 5 & 95 & 107 & 96 & 100 \\
\hline Challenger & 3.9 & 3.8 & 13 & 88 & 72 & 84 & 65 \\
\hline Champ & 4.3 & 4.4 & 9 & 87 & 94 & 86 & 74 \\
\hline Chase & 4.4 & 4.4 & 21 & 83 & 84 & 95 & 72 \\
\hline Chieftain & 2.9 & 4.3 & 13 & 94 & 108 & 94 & 111 \\
\hline Commander & 4.7 & 4.4 & 27 & 94 & 74 & 95 & 52 \\
\hline Cornucopia & 4.1 & 4.5 & 30 & 85 & 80 & 94 & 72 \\
\hline Crisp n Sweet 710 & 4.0 & 4.2 & 12 & 94 & 85 & 85 & 83 \\
\hline DMC 20-38 & $\ldots$ & 6.5 & 36 & $\ldots$ & 47 & $\ldots$ & 35 \\
\hline Early Cogent & 4.0 & 4.4 & 16 & 99 & 92 & 83 & 90 \\
\hline Eliminator & 2.5 & 2.1 & 1 & 94 & 104 & 96 & 97 \\
\hline Elite & 4.3 & 4.5 & 32 & 85 & 87 & 98 & 54 \\
\hline Empire & 4.5 & 6.0 & 61 & 93 & 51 & 92 & 44 \\
\hline Esquire & 3.9 & 4.0 & 23 & 91 & 102 & 96 & 79 \\
\hline Excalibur & 4.1 & 4.6 & 32 & 94 & 80 & 94 & 77 \\
\hline Excellency & 3.6 & 3.9 & 16 & 93 & 91 & 94 & 68 \\
\hline FMX 413 WS & 4.8 & 5.2 & 30 & 81 & 79 & 84 & 74 \\
\hline GG Code 1 & 3.8 & 3.9 & 5 & 87 & 105 & 101 & 107 \\
\hline GG Code 11 & 6.0 & 6.3 & 63 & 69 & 37 & 80 & 33 \\
\hline GG Code 17 & 3.9 & 3.1 & 2 & 85 & 110 & 86 & 122 \\
\hline GG Code 23 & 4.5 & 4.3 & 26 & 92 & 81 & 71 & 49 \\
\hline GG Code 26 & 3.3 & & 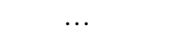 & 92 & & 103 & \\
\hline GG Code 37 & $\ldots$ & 2.5 & 3 & $\ldots$ & 107 & $\ldots$ & 101 \\
\hline GG Code 49 & 4.7 & 3.9 & 3 & 89 & 107 & 86 & 94 \\
\hline GG Code 55 & 2.7 & $\ldots$ & $\ldots$ & 106 & $\ldots$ & 93 & $\ldots$ \\
\hline GG Code 58 & & 4.6 & 14 & & 81 & & 69 \\
\hline GG Code 59 & 2.9 & 2.2 & 1 & 99 & 96 & 92 & 76 \\
\hline GG Code 6 & 2.6 & 3.0 & 3 & 99 & 82 & 97 & 59 \\
\hline GG Code 62 & & 2.3 & 1 & & 98 & $\ldots$ & 93 \\
\hline GG Code 67 & 2.9 & 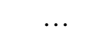 & $\ldots$ & 94 & & 89 & $\ldots$ \\
\hline GH 2628 & 3.3 & 3.1 & 16 & 90 & 85 & 85 & 68 \\
\hline GH 2690 & 4.7 & 5.4 & 51 & 86 & 53 & 97 & 43 \\
\hline GSS 4606 & $\ldots$ & 3.2 & 9 & & 91 & $\ldots$ & 91 \\
\hline GSS 7831 & 4.5 & 4.4 & 11 & 97 & 76 & 91 & 68 \\
\hline GSS 9299 & 4.1 & 5.4 & 33 & 86 & 103 & 90 & 90 \\
\hline HMX 5371 & 2.7 & 2.0 & 1 & 91 & 96 & 88 & 95 \\
\hline Heritage & 6.4 & 7.2 & 86 & 76 & 30 & 94 & 10 \\
\hline HM 701 & 3.6 & 4.1 & 6 & 89 & 79 & 93 & 43 \\
\hline HMX 3392 S & 4.3 & 4.7 & 43 & 85 & 76 & 94 & 84 \\
\hline HMX 5375 S & 3.8 & $\ldots$ & $\ldots$ & 96 & $\ldots$ & 96 & $\ldots$ \\
\hline HMX $6382 \mathrm{~S}$ & 3.6 & $\ldots$ & $\ldots$ & 87 & $\ldots$ & 84 & $\ldots$ \\
\hline HMX $9352 \mathrm{~S}$ & 4.6 & $\ldots$ & $\ldots$ & 87 & $\ldots$ & 80 & $\ldots$ \\
\hline Jubilee & 6.2 & 7.0 & 80 & 66 & 28 & 67 & 10 \\
\hline Lumina & 5.3 & 6.2 & 64 & 73 & 55 & 83 & 56 \\
\hline Reveille & 3.8 & 5.6 & 24 & 87 & 68 & 85 & $\ldots$ \\
\hline Rival & 4.0 & 4.9 & 20 & 92 & 69 & 91 & 68 \\
\hline Royal Sweet & 3.9 & 5.3 & 45 & 91 & 34 & 68 & 30 \\
\hline Seneca Nation & & 2.3 & 0 & & 102 & & 101 \\
\hline Sprint & 5.1 & 6.7 & 74 & 80 & 35 & 87 & 16 \\
\hline Summer Sweet 7631 & 3.0 & 3.1 & 2 & 89 & 95 & 86 & 100 \\
\hline Summer Sweet 781 Ultra & 3.2 & 3.4 & 2 & 89 & 114 & 77 & 83 \\
\hline Sure Gold & & 3.2 & 9 & $\ldots$ & 94 & $\ldots$ & 89 \\
\hline Temptation & 4.4 & 4.7 & 20 & 88 & 85 & 91 & 52 \\
\hline Terminator & 2.6 & 2.7 & 3 & 97 & 104 & 89 & 115 \\
\hline Topacio & 3.1 & 3.5 & 6 & 94 & 83 & 87 & 84 \\
\hline Tracer & 5.2 & 5.1 & 40 & 80 & 70 & 86 & 83 \\
\hline Trigger & 2.6 & 2.7 & 5 & 94 & 95 & 83 & 88 \\
\hline Vanguard & 3.0 & 3.5 & 18 & 96 & 84 & 93 & 62 \\
\hline WHT 2801 & 3.5 & 3.2 & 6 & 100 & 90 & 97 & 78 \\
\hline XSC 1040 & 4.5 & 4.6 & 46 & 79 & 84 & 74 & 64 \\
\hline FLSD $(\alpha=0.05)$ & 0.54 & 0.73 & 14.2 & 8.9 & 23.6 & 23.0 & 52.5 \\
\hline Mean & 4.0 & 4.3 & 24.7 & 88.2 & 80.5 & 87.5 & 70.3 \\
\hline
\end{tabular}

a Stewart's rating: 1 (no spread) to 9 (dead plants) in inoculated treatment.

${ }^{b}$ Incidence of systemic infection $=$ (number of systemically infected plants $/$ total number of plants $) \times 100$.

${ }^{\mathrm{c}}$ Percent yield (ear weight) $=($ ear weight from inoculated subplots / ear weight from noninoculated subplots $) \times 100$.

$\mathrm{d}$ Percent marketable ears $=$ (number of marketable ears from inoculated subplots $/$ number of marketable ears from noninoculated plots $) \times 100$.

e $\ldots=$ no data recorded. 
inoculated. In 1999, each experimental unit was a two-row plot that was $3.6 \mathrm{~m}$ long with 16 plants per row. Experimental units in 2000 were two-row plots that were 4.9 m long with 24 plants per row. In 2000, all seed was treated with thiamethoxam (Cruiser, SyngentaCrop Protection, Greensboro, NC) at a rate of $250 \mathrm{~g}$ a.i. per $100 \mathrm{~kg}$ of seed to reduce natural Stewart's wilt infection (14).

As soon as plants were large enough (i.e., two- to three-leaf stage on 4 June 1999 and 30 May 2000), they were inoculated with $E$. stewartii using the pinprick method $(2,4)$ Plants were inoculated again at three- to six-leaf stages on 8 and 18 June 1999 and 6 and 8 June 2000. At all inoculations, the two or three leaves that formed the leaf whorl were wounded with needles, and inoculum on sponges was introduced into wounds. Inoculum was produced from a mixture of isolates collected in Illinois from naturally infected corn leaves in 1998 and 1999. Isolates were maintained as a bulked population on infected corn grown in the greenhouse. Inoculum was prepared by transferring about 1 dozen 2 -cm pieces of surface-sterilized, E. stewartii-infected leaf tissue to sterilized nutrient broth in Erlenmeyer flasks. Cultures were incubated at room temperature on shakers for approximately $15 \mathrm{~h}$. Shake cultures were diluted 10-fold with $0.1 \mathrm{M} \mathrm{NaCl}$ before using as inoculum. All inoculated experimental units were treated the same, but inoculum concentration was not measured.

Stewart's wilt symptoms were rated 26 June 1999 and 22 June 2000 (2 to 3 weeks after inoculation) while plants still had leaf whorls and again 1 week before harvest began both years. Each experimental unit was given six ratings (three per row) from 1 to 9 for which $1=$ no spread of symptoms from inoculation wounds; 2 = little spread, with chlorosis and necrosis within $5 \mathrm{~cm}$ of inoculation wounds; $3=$ limited spread, with water-soaking, chlorosis, and necrosis toward the tip end only of inocu-

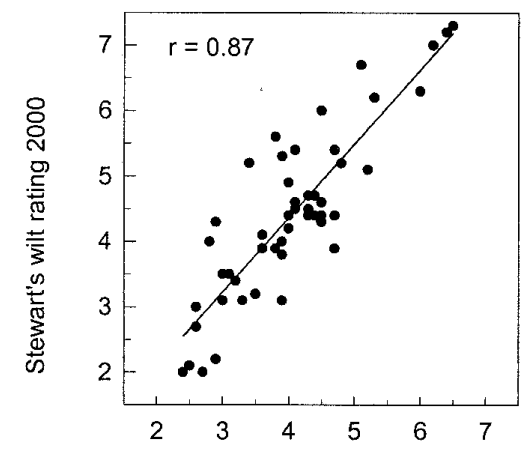

Stewart's wilt rating 1999

Fig. 1. Stewart's wilt severity ratings (1 to 9) for 50 sweet corn hybrids inoculated at the two- to six-leaf stages with Erwinia stewartii in 1999 and 2000. lated leaves; 4 = abundant spread, with water-soaking, chlorosis, and necrosis toward both ends of inoculated leaves or slight (one or two leaves) systemic infection of plants; $5=$ limited systemic infection of entire plants, with chlorosis, watersoaking, wilting, chlorosis, and/or necrosis of noninoculated leaves; $6=$ severe watersoaking, wilting, chlorosis, and/or necrosis of 25 to $50 \%$ of the total leaf area, with stunting; 7 = severe chlorosis, necrosis, and wilting of 50 to $70 \%$ of the total leaf area, with severe stunting; $8=$ severe chlorosis and necrosis of 75 to $90 \%$ of the leaf area; and $9=$ dead or nearly dead plants. The six ratings per experimental unit were averaged. Plants with systemic Stewart's wilt were counted in noninoculated subplots 26 June 1999 and in noninoculated and inoculated subplots 23 June 2000. Plants were considered systemically infected if long, linear, chlorotic or watersoaked symptoms of Stewart's wilt were observed on noninoculated leaves. Incidence of systemic infection was calculated as a percentage for each experimental unit.

Primary ears were harvested about 21 days after midsilk from 10 and 15 consecutive plants in each of the two rows per experimental unit in 1999 and 2000, respectively. Immediately after harvest, ears were weighed with and without husk leaves. Ear weight was converted to metric tons per hectare. The numbers of marketable and nonmarketable ears also were counted. Ears were considered marketable if they were at least $17 \mathrm{~cm}$ long with at least 12 rows of kernels and about $95 \%$ kernel fill. Percent yield was calculated for each main plot (hybrid within replicate) by dividing ear weight from inoculated treatments by ear weight from noninoculated treatments and multiplying by 100 . Percent marketable ears was calculated for each main plot by dividing the number of marketable ears from inoculated treatments by the number of marketable ears from non-

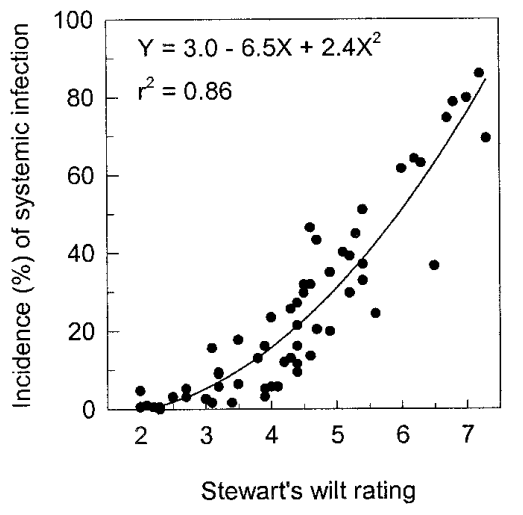

Fig. 2. Percent incidence of systemic Stewart's wilt infection and Stewart's wilt severity ratings ( 1 to 9 ) for 60 sweet corn hybrids inoculated at the two- to six-leaf stages with Erwinia stewartii in 2000. inoculated treatments and multiplying by 100.

The effects of hybrids and inoculation treatments on ear weight, marketable ears, and systemic infection were assessed by analysis of variance (ANOVA) for a splitplot experimental design with a factorial treatment design. The effects of hybrids on Stewart's wilt ratings in inoculated subplots, percent yield (ear weight and marketable ears) were compared by FLSDvalues following ANOVA. Mean Stewart's wilt ratings for hybrids were correlated between years. In both years, percent yield and percent marketable ears were regressed on Stewart's wilt ratings calculated as a mean of the two assessments, about 3 weeks after inoculation and 1 week before harvest. In 2000, percent yield (ear weight) and percent marketable ears also were regressed on incidence of systemic Stewart's wilt infection in inoculated plots. Hybrid mean values were used for regression analyses using the GLM procedure of SAS (SAS Institute, Cary, NC).

\section{RESULTS}

Stewart's wilt was more severe in 2000 than in 1999, particularly on hybrids with moderate to susceptible reactions (Table 1). Hybrid means for Stewart's wilt ratings in inoculated treatments ranged from 2.4 to 6.5 in 1999 and from 2.0 to 7.3 in 2000 . Sweet corn hybrids were a significant source of variation $(P<0.05)$ in the ANOVA of Stewart's wilt ratings. Stewart's wilt ratings for 50 hybrids in both trials were correlated $(r=0.87)$ between years (Fig. 1).

Incidence of systemic Stewart's wilt infection in noninoculated plots in 1999 ranged from 0 to $40 \%$ with a grand mean of $8.7 \%$ (data not shown). When seed treatment insecticides were applied in 2000, incidence of systemic Stewart's wilt in noninoculated and inoculated plots ranged from 0 to $7 \%$ and 0 to $86 \%$, respectively, with grand means of $1.3 \%$ (data not shown) and $24.7 \%$, respectively (Table 1 ). Hybrids, inoculation treatments, and the hybrid-by-treatment interaction were significant sources $(P<0.05)$ of variation in the ANOVA of Stewart's wilt incidence in 2000. The relationship between Stewart's wilt ratings and incidence of systemic infection in inoculated treatments in 2000 was described by a quadratic regression (Fig. 2). Based on this regression, incidence of systemic infection was less than $5 \%$ for hybrids with Stewart's wilt ratings of 2 or 3 . For hybrids with Stewart's ratings of $4,5,6$, or 7, incidence of systemic infection was estimated to be about 15,30 , 50 , and $75 \%$, respectively.

Yield, measured as ear weight, was more variable and lower in 2000 than in 1999 (Table 2). Hybrid mean yield from inoculated and noninoculated treatments in 1999 ranged from 11.7 to 21.7 tons/ha and from 15.6 to 23.6 tons/ha, respectively (Table 2). 
Table 2. Ear weight and number of marketable ears for sweet corn hybrids inoculated or not inoculated with Erwinia stewartii in 1999 and 2000

\begin{tabular}{|c|c|c|c|c|c|c|c|c|}
\hline \multirow[b]{3}{*}{ Hybrid } & \multicolumn{4}{|c|}{ Ear weight (tons/ha) } & \multicolumn{4}{|c|}{ Marketable ears $^{a}$} \\
\hline & \multicolumn{2}{|c|}{1999} & \multicolumn{2}{|c|}{2000} & \multicolumn{2}{|c|}{1999} & \multicolumn{2}{|c|}{2000} \\
\hline & $\mathbf{N I}^{\mathbf{b}}$ & I & NI & I & NI & I & NI & I \\
\hline ACX 405 & 18.2 & 14.2 & $\ldots{ }^{c}$ & $\ldots$ & 18 & 12 & $\ldots$ & $\ldots$ \\
\hline ACX 420 & 18.9 & 15.4 & $\ldots$ & $\ldots$ & 17 & 13 & $\ldots$ & $\ldots$ \\
\hline $\mathrm{ACX} 427$ & 21.2 & 13.8 & $\ldots$ & $\ldots$ & 15 & 10 & $\ldots$ & $\ldots$ \\
\hline ACX 500 & $\ldots$ & $\ldots$ & 8.0 & 6.9 & $\ldots$ & $\ldots$ & $\ldots$ & $\ldots$ \\
\hline ACX 502 & $\ldots$ & $\ldots$ & 10.4 & 8.1 & $\ldots$ & $\ldots$ & 8 & 5 \\
\hline ACX 610 & $\ldots$ & $\ldots$ & 14.4 & 3.7 & $\ldots$ & $\ldots$ & 14 & 1 \\
\hline Ambrosia & 18.3 & 16.8 & 14.3 & 13.8 & 20 & 17 & 18 & 17 \\
\hline Beretta & 18.3 & 11.7 & 15.1 & 5.1 & 14 & 5 & 8 & 2 \\
\hline Bonanza & 20.5 & 19.5 & 10.8 & 9.2 & 19 & 15 & 11 & 8 \\
\hline Bonus & 19.7 & 18.5 & 15.5 & 16.5 & 19 & 17 & 17 & 17 \\
\hline Challenger & 17.5 & 15.3 & 9.1 & 6.3 & 18 & 14 & 12 & 8 \\
\hline Champ & 17.4 & 15.2 & 14.1 & 13.1 & 18 & 15 & 12 & 9 \\
\hline Chase & 18.8 & 15.6 & 13.5 & 11.4 & 18 & 12 & 20 & 14 \\
\hline Chieftain & 17.6 & 16.6 & 9.6 & 10.3 & 20 & 13 & 11 & 13 \\
\hline Commander & 21.9 & 20.5 & 11.1 & 7.9 & 15 & 14 & 8 & 4 \\
\hline Cornucopia & 21.0 & 17.5 & 17.2 & 13.6 & 17 & 11 & 15 & 11 \\
\hline Crisp n Sweet 710 & 16.9 & 15.8 & 11.9 & 9.2 & 18 & 14 & 15 & 12 \\
\hline DMC $20-38$ & $\ldots$ & $\ldots$ & 18.5 & 8.3 & $\ldots$ & $\ldots$ & 18 & 6 \\
\hline Early Cogent & 19.4 & 19.2 & 12.4 & 11.2 & 16 & 11 & 13 & 12 \\
\hline Eliminator & 21.8 & 20.3 & 20.3 & 19.8 & 19 & 14 & 27 & 26 \\
\hline Elite & 23.6 & 20.1 & 15.2 & 12.7 & 17 & 14 & 14 & 7 \\
\hline Empire & 18.7 & 17.3 & 16.3 & 8.2 & 17 & 10 & 19 & 8 \\
\hline Esquire & 19.6 & 17.7 & 14.3 & 14.6 & 19 & 17 & 18 & 15 \\
\hline Excalibur & 19.8 & 18.4 & 18.0 & 14.6 & 18 & 14 & 24 & 18 \\
\hline Excellency & 20.2 & 18.8 & 18.4 & 16.5 & 18 & 16 & 26 & 18 \\
\hline FMX 413 WS & 19.5 & 15.7 & 14.3 & 11.4 & 15 & 12 & 18 & 13 \\
\hline GG Code 1 & 17.6 & 15.1 & 12.0 & 12.5 & 19 & 14 & 14 & 15 \\
\hline GG Code 11 & 19.8 & 13.6 & 10.8 & 4.1 & 16 & 11 & 14 & 5 \\
\hline GG Code 17 & 18.4 & 15.5 & 12.8 & 14.3 & 19 & 16 & 13 & 16 \\
\hline GG Code 23 & 21.5 & 19.7 & 16.2 & 13.0 & 16 & 10 & 18 & 9 \\
\hline GG Code 26 & 23.0 & 21.1 & $\ldots$ & $\ldots$ & 19 & 17 & $\ldots$ & $\ldots$ \\
\hline GG Code 37 & $\ldots$ & $\ldots$ & 16.1 & 17.2 & $\ldots$ & $\ldots$ & 19 & 20 \\
\hline GG Code 49 & 18.8 & 16.7 & 14.1 & 14.7 & 18 & 14 & 20 & 19 \\
\hline GG Code 55 & 21.2 & 21.7 & $\ldots$ & $\ldots$ & 17 & 13 & $\ldots$ & $\ldots$ \\
\hline GG Code 58 & $\ldots$ & $\ldots$ & 19.0 & 15.2 & $\ldots$ & $\ldots$ & 22 & 15 \\
\hline GG Code 59 & 16.5 & 16.4 & 17.4 & 16.6 & 20 & 17 & 28 & 21 \\
\hline GG Code 6 & 20.8 & 20.6 & 15.0 & 12.3 & 17 & 16 & 18 & 11 \\
\hline GG Code 62 & $\ldots$ & $\ldots$ & 19.1 & 18.5 & $\ldots$ & $\ldots$ & 28 & 26 \\
\hline GG Code 67 & 22.5 & 21.1 & $\ldots$ & $\ldots$ & 19 & 14 & $\ldots$ & $\ldots$ \\
\hline GH 2628 & 21.3 & 19.1 & 16.8 & 14.2 & 18 & 15 & 21 & 15 \\
\hline GH 2690 & 21.0 & 17.7 & 16.3 & 8.8 & 16 & 11 & 12 & 5 \\
\hline GSS 4606 & $\ldots$ & $\ldots$ & 8.8 & 7.7 & $\ldots$ & $\ldots$ & 12 & 11 \\
\hline GSS 7831 & 17.1 & 16.3 & 15.1 & 11.6 & 18 & 15 & 22 & 15 \\
\hline GSS 9299 & 18.7 & 16.1 & 14.1 & 13.2 & 18 & 16 & 20 & 18 \\
\hline Heritage & 16.5 & 12.4 & 14.6 & 4.5 & 16 & 10 & 20 & 2 \\
\hline HM 701 & 16.5 & 14.7 & 10.8 & 8.5 & 19 & 16 & 14 & 6 \\
\hline HMX 3392 S & 18.4 & 15.6 & 17.0 & 13.0 & 14 & 11 & 17 & 14 \\
\hline HMX 5371 & 20.6 & 18.8 & 17.8 & 17.1 & 20 & 17 & 23 & 22 \\
\hline HMX $5375 \mathrm{~S}$ & 18.9 & 18.0 & $\ldots$ & $\ldots$ & 19 & 18 & $\ldots$ & $\ldots$ \\
\hline HMX $6382 \mathrm{~S}$ & 16.9 & 14.8 & $\ldots$ & $\ldots$ & 20 & 12 & $\ldots$ & $\ldots$ \\
\hline HMX $9352 \mathrm{~S}$ & 15.6 & 13.6 & $\ldots$ & $\ldots$ & 18 & 12 & $\ldots$ & $\ldots$ \\
\hline Jubilee & 18.9 & 12.4 & 11.2 & 3.3 & 15 & 9 & 15 & 2 \\
\hline Lumina & 20.5 & 14.6 & 16.1 & 9.4 & 17 & 12 & 18 & 10 \\
\hline Reveille & 17.1 & 14.9 & 11.2 & 7.5 & 19 & 13 & $\ldots$ & $\ldots$ \\
\hline Rival & 17.5 & 16.1 & 13.1 & 9.2 & 18 & 14 & 19 & 13 \\
\hline Royal Sweet & 18.8 & 17.2 & 12.3 & 4.2 & 15 & 6 & 13 & 4 \\
\hline Seneca Nation & $\ldots$ & $\ldots$ & 14.2 & 14.2 & $\ldots$ & $\ldots$ & 26 & 26 \\
\hline Sprint & 18.0 & 14.5 & 11.5 & 4.0 & 18 & 13 & 11 & 2 \\
\hline Summer Sweet 7631 & 19.3 & 17.1 & 10.7 & 10.3 & 18 & 15 & 14 & 14 \\
\hline Summer Sweet 781 Ultra & 17.1 & 15.2 & 7.1 & 8.1 & 19 & 14 & 10 & 8 \\
\hline Sure Gold & $\ldots$ & $\ldots$ & 15.5 & 14.6 & $\ldots$ & $\ldots$ & 24 & 21 \\
\hline Temptation & 16.8 & 14.8 & 11.9 & 10.0 & 19 & 16 & 7 & 4 \\
\hline Terminator & 19.0 & 18.4 & 14.6 & 15.0 & 19 & 15 & 15 & 18 \\
\hline Topacio & 21.4 & 20.1 & 17.7 & 14.6 & 20 & 16 & 23 & 20 \\
\hline Tracer & 21.5 & 17.1 & 14.4 & 9.8 & 15 & 11 & 12 & 10 \\
\hline Trigger & 19.5 & 18.2 & 13.2 & 12.3 & 19 & 14 & 11 & 9 \\
\hline Vanguard & 18.6 & 17.9 & 14.0 & 11.6 & 17 & 13 & 21 & 13 \\
\hline WHT 2801 & 19.9 & 19.9 & 16.0 & 14.1 & 19 & 15 & 22 & 17 \\
\hline XSC 1040 & 17.9 & 14.1 & 12.2 & 10.1 & 17 & 11 & 20 & 13 \\
\hline FLSD $(0.05)$ & 1.39 & 1.53 & 3.38 & 3.17 & 2.1 & 3.2 & 7.0 & 6.4 \\
\hline Mean & 19.2 & 16.9 & 14.1 & 11.2 & 17.6 & 13.4 & 16.3 & 11.9 \\
\hline
\end{tabular}

a Number of marketable primary ears harvested from 20 or 30 plants in 1999 and 2000, respectively.

b $\mathrm{NI}=$ noninoculated, $\mathrm{I}=$ inoculated.

c $\ldots=$ no data recorded. 
Hybrid mean yield from inoculated and noninoculated treatments in 2000 ranged from 3.3 to 19.8 tons/ha and from 7.1 to 20.3 tons/ha, respectively. Hybrids, inoculation treatments, and the hybrid-bytreatment interaction were significant sources of variation in the ANOVA for yield based on ear weight in 1999 and 2000.

Yield, measured as marketable ears, also was more variable in 2000 than in 1999 (Table 2). Hybrid means for the number of marketable ears in noninoculated and inoculated treatments in 1999 ranged from 14 to 20 per plot and 5 to 18 per plot, respectively (Table 2). Hybrid means for the number of marketable ears in noninoculated and inoculated treatments in 2000 ranged from 7 to 28 per plot and 1 to 26 per plot, respectively. Hybrids, inoculation treatments, and the hybrid-by-treatment interaction were significant sources of variation in the ANOVA for number of marketable ears in 1999 and 2000.

Hybrids were a significant source of variation in the ANOVA of percent yield based on ear weight (Table 1). Hybrid means for percent yield (ear weight) ranged from 64 to $106 \%$ in 1999, and from 26 to $114 \%$ in 2000 (Table 1). Over both trials, ear weight from inoculated treatments was within $90 \%$ of that from noninoculated treatments for 21 of 23 hybrids rated 3 or below and for 23 of 34 hybrids rated from 3 to 4 (Table 3). Ear weight from inoculated treatments was within $90 \%$ of that from noninoculated treatments for only 8 of 35 hybrids rated from 4 to 5 , and for just 1 of 27 hybrids rated 5 or above (Table 3).

Hybrids also were a significant source $(P<0.05)$ of variation in the ANOVA of percent marketable ears (Table 1). Hybrids' means for percent marketable ears ranged from 55 to $103 \%$ (Table 1). In both trials, the number of marketable ears from inoculated treatments was within $90 \%$ of that from noninoculated treatments for 15 of 23 hybrids rated 3 or below (Table 3 ). The number of marketable ears from inoculated treatments was within $90 \%$ of that from noninoculated treatments for only 14 of 34 hybrids rated from 3 to 4 , for 13 of 35 hybrids rated from 4 to 5 , and for 3 of 27 hybrids rated 5 or above (Table 3 ).

The relationships between percent yield (ear weight) and Stewart's wilt ratings were best described by quadratic regressions in both years (Fig. 3). Based on these regression equations, yield (based on ear weight) of hybrids with Stewart's wilt ratings below 3 was estimated to be at least $94 \%$ of the yield from noninoculated treatments of those hybrids (i.e., maximum yield of $100 \%$ ). For hybrids with Stewart's ratings of 4 , yield was about $90 \%$ of the maximum (i.e., yield reductions of about $10 \%$ ). Estimated yield reductions for hybrids with Stewart's wilt ratings of 5, 6, or 7 were 18, 29, and 43\% in 1999 and 23, 43, and $67 \%$ in 2000 , respectively.

Percent marketable ears was a more variable trait than percent yield as ear weight, but the relationships between percent marketable ears and Stewart's wilt ratings also were best described by quadratic regressions (Fig. 3). Based on these regression equations, the number of marketable ears from hybrids with Stewart's wilt ratings of 4 or below in 1999 or ratings of 3 or below in 2000 was estimated to be at least $90 \%$ of the number of marketable ears from noninoculated treatments of those hybrids (i.e., maximum yield of $100 \%)$. For hybrids with Stewart's ratings of 4 in 2000 , yields were about $80 \%$ of the maximum (i.e., yield reductions of about $20 \%$ ). Estimated yield reductions for hybrids with Stewart's wilt ratings of 5, 6, or 7 were 16, 25, and 36\% in 1999 and 35, 55, and $80 \%$ in 2000 , respectively.

The relationships between percent yield (ear weight or marketable ears) and incidence of systemic infection in 2000 were best described by linear equations (Fig. 4). Percent yield was reduced about $0.9 \%$ for each $1 \%$ incidence of systemic infection.

\section{DISCUSSION}

The adverse effects of Stewart's wilt on ear weight and number of marketable ears were minor for sweet corn hybrids with levels of resistance that prevented or minimized systemic infection. A level of resistance that resulted in Stewart's wilt ratings below 3 or 3.5 corresponded to nonsystemic infection of most plants (i.e., incidence of systemic infection below 5 or $10 \%$, respectively). Relationships between Stewart's wilt severity ratings and yield reductions were curvilinear; whereas yield reductions increased linearly with the incidence of systemic infection in 2000. Thus, it appeared that mild infection that was not

Table 3. Number of sweet corn hybrids inoculated with Erwinia stewartii in 1999 and 2000 for which ear weight and number of marketable ears were within $90 \%$ of noninoculated treatments

\begin{tabular}{lccc}
\hline & & \multicolumn{2}{c}{ Hybrids within 90\% of control } \\
\cline { 3 - 4 } Stewart's wilt rating $^{\mathbf{a}}$ & Number of hybrids $^{\mathbf{b}}$ & Ear weight & Marketable ears \\
\hline$\leq 3$ & 23 & 21 & 15 \\
3 to $\leq 4$ & 34 & 23 & 14 \\
4 to $<5$ & 35 & 8 & 13 \\
$\geq 5$ & 27 & 1 & 3 \\
\hline
\end{tabular}

a Stewart's rating: 1 (no spread) to 9 (dead plants) in inoculated treatment.

${ }^{\mathrm{b}}$ Hybrid-by-year combinations. systemic had little effect on yield. Ear weights of hybrids with ratings below 3 or 3.5 were estimated from the regression equations to be within 95 or $92 \%$, respectively, of those from noninoculated plants of the same hybrid. The number of marketable ears from hybrids with ratings of 3 or below was estimated from the regression equations to be within $90 \%$ of those from noninoculated plants of the same hybrid.

Stewart's wilt severity ratings for nine hybrids (Eliminator, GG Code 37, GG Code 55, GG Code 59, GG Code 62, HMX 5371, Seneca Nation, Terminator, and Trigger) were not significantly different from Bonus, the hybrid with the lowest rating in both trials. Ratings for three hybrids (Ambrosia, Chieftain, and GG Code 6) were not different from Bonus in the 1999 trial. Many other sweet corn hybrids developed recently that were not included in this study have Stewart's wilt reactions similar to these 13 hybrids (11). Ear weight from inoculated treatments of these hybrids was within $91 \%$ of that from noninoculated treatments except for GG Code 6 in the trial in 2000. The number of marketable ears from inoculated treatments of these hybrids was within $88 \%$ of that from noninoculated treatments except for Trigger

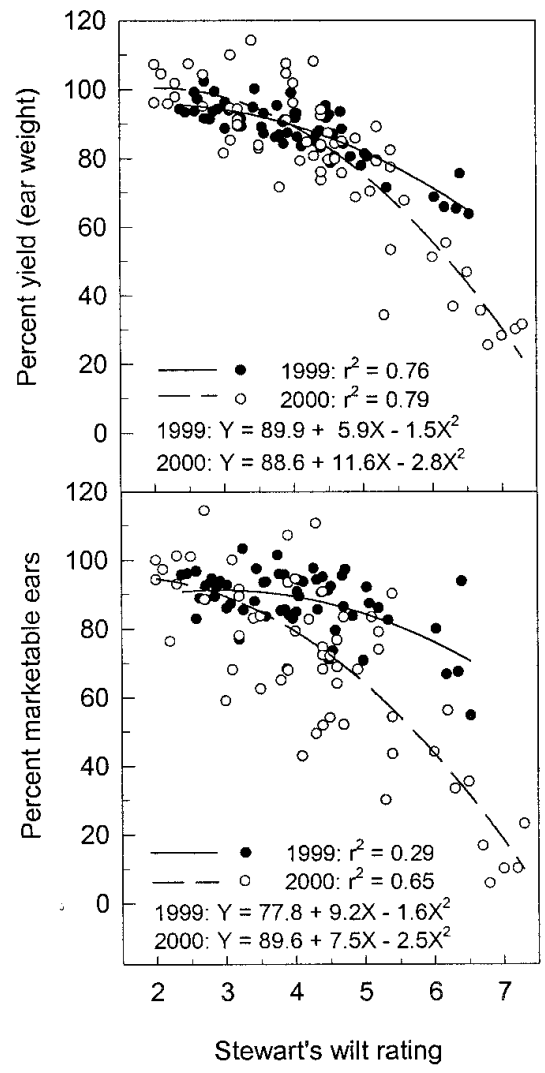

Fig. 3. Stewart's wilt severity ratings (1 to 9) and yield measured as ear weight or number of marketable ears from inoculated treatments as a percentage of yield from noninoculated treatments for sweet corn hybrids inoculated at the two- to six-leaf stages with Erwinia stewartii in 1999 and 2000. 
and GG Code 59 in the 1999 trial and GG Code 6 in both trials.

Relationships between Stewart's wilt severity and yield in this study are similar to previous observations of the effects of Stewart's wilt on sweet corn yield. Sweet corn yield was affected minimally (i.e., within $90 \%$ of the maximum) when Stewart's wilt severity was less than 10 or $15 \%$ (i.e., ratings between 4 and 5) in a study in which severity ranged from 0 to $60 \%$ as a result of different levels of host resistance (13). Sweet corn yield also was affected minimally when Stewart's wilt severity was less than $40 \%$ (i.e., ratings of ca. 6) in a study in which severity ranged from 0 to $100 \%$ as a result of different growth stages at which susceptible hybrids were inoculated with E. stewartii (18). In the present study, levels of resistance that prevented yield reductions were associated with ratings from 3 to 4 , which corresponded to about 3 to $15 \%$ severity.

The relationship between incidence of systemic infection and yield in this study also is similar to previous observations. Suparyono and Pataky (19) observed linear relationships with slope coefficients from 0.3 to -1.15 when percent yield (ear weight and marketable ears) was regressed on incidence of infection of susceptible sweet corn hybrids inoculated at various growth stages between the three- and seven-leaf. Jacobsen et al. (9) observed decreases in yield of all sweet corn cultivars having

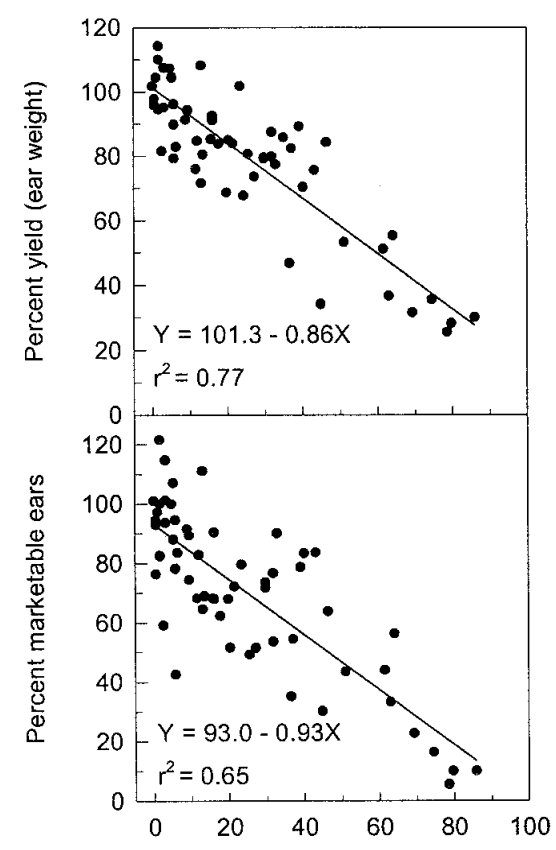

Systemically infected plants (\%)

Fig. 4. Incidence (\%) of systemic Stewart's infection and yield measured as ear weight or number of marketable ears from inoculated treatments as a percentage of yield from noninoculated treatments for sweet corn hybrids inoculated at the two- to six-leaf stages with Erwinia stewartii in 2000. symptoms at the time of silking. They concluded that yield losses were minimal for cultivars with less than $10 \%$ incidence of symptomatic plants, and yield of cultivars with 10 to $30 \%$ incidence was satisfactory under light disease pressure but it was unsatisfactory when disease pressure was severe. In our study, yield was decreased about $9 \%$ for each $10 \%$ incidence of systemic Stewart's wilt infection.

In our study, Stewart's wilt had a lesser impact on yield of hybrids with ratings above 4 in 1999 than in 2000. This probably was due to a higher level of natural infection in the trial in 1999 and the method used to calculate percent yield. In 1999, incidence of systemic infection in the noninoculated treatment was as high as $40 \%$ for some hybrids, particularly those that were more susceptible to Stewart's wilt, and yields from the noninoculated control treatment of these hybrids probably was reduced. Therefore, yields from the inoculated treatments of these hybrids were inflated when they were calculated as a percentage of the yields from the noninoculated treatments. In 2000, natural infection of noninoculated treatments was minimized by applying thiamethoxam to seed before planting.

Although yield was not affected substantially for hybrids with levels of resistance corresponding to Stewart's wilt severity ratings below 3, yield may be affected when these hybrids are grown under more severe disease pressure, as noted by Jacobsen et al. (9). When flea beetles are abundant due to mild winter temperatures and dry conditions early in the growing season, moderately resistant and resistant hybrids can be systemically infected as a result of flea beetle feeding and infection at the time plants are emerging, i.e., prior to the two- or three-leaf stage (12). In such cases, main stalks may be killed if E. stewartii infects the growing point of the plant. Incidence of systemic infection and main stalk death under severe Stewart's wilt pressure are associated with levels of resistance (10). Thus, higher levels of resistance are beneficial when main stalk death is prevalent due to large populations of flea beetles.

In addition to resistance, seed treatment insecticides also can be used to reduce incidence of systemic Stewart's wilt infection by about 50 to $85 \%$ relative to nontreated controls (14). Seed treatment insecticides may not be necessary under most conditions if hybrids have levels of resistance that prevent systemic infection. However, they may be useful on these hybrids when flea beetles are abundant and main stalk death occurs as a result of infection at emergence. For hybrids that do not have adequate levels of resistance to prevent systemic infection when plants are infected at later growth stages (e.g., threeto five-leaf stages), the relationship observed in this study between incidence of systemic infection and sweet corn yield provides an estimate of yield losses that should be helpful in determining when seed treatment insecticides are economical.

In order to minimize yield losses due to Stewart's wilt in sweet corn, levels of resistance that prevent systemic infection are necessary. Any breeding line with a Stewart's wilt rating less than 3.5 may be potentially useful in developing resistant hybrids and should be evaluated for other characteristics of importance. Sweet corn inbred lines with moderately resistant reactions (i.e., ratings of 3 to 3.5) may be adequate in hybrid combination if resistance is conditioned by dominant gene action. If resistance is additive, inbred lines with higher levels of resistance would be preferred in crosses with susceptible inbreds. Gene action may differ among various sources of Stewart's wilt resistance.

\section{LITERATURE CITED}

1. Ayers, J. E., MacNab, A. A., Tetrault, R. C., and Yocum, J. O. 1979. The influence of selected insecticides on yield and the incidence of Stewart's wilt in sweet corn. Plant Dis. Rep. 63:634-638.

2. Blanco, M. H., Johnson, M. G., Colbert, T. R., and Zuber, M. S. 1977. An inoculation technique for Stewart's wilt disease of corn. Plant Dis. Rep. 61:413-416.

3. Braun, E. J. 1982. Ultrastructural investigation of resistant and susceptible maize inbreds infected with Erwinia stewartii. Phytopathology $72: 159-166$

4. Chang, C. M., Hooker, A. L., and Lim, S. M. 1977. An inoculation technique for determining Stewart's bacterial blight reaction in corn. Plant Dis. Rep. 61:1077-1079.

5. Goth, R. W., and Stienke, J. 1977. Studies on the incidence of Stewart's wilt in sweet corn. (Abstr.) Proc. Am. Phytopathol. Soc. 4:215.

6. Ivanhoff, S. S. 1933. Stewart's wilt disease of corn, with emphasis on the life history of Phytomonas stewartii in relation to pathogenesis. J. Agric. Res. 47:749-769.

7. Ivanhoff, S. S. 1936. Resistance to bacterial wilt of open-pollinated varieties of sweet, dent and flint corn. J. Agric. Res. 53:917-926.

8. Ivanhoff, S. S., and Riker, A. J. 1936. Resistance to bacterial wilt of inbred strains and crosses of sweet corn. J. Agric. Res. 53:927954.

9. Jacobsen, B. J., Courter, J. W., Milbrath, G. M., and McKibben, G. E. 1977. Evaluation of sweet corn cultivars for yield and resistance to Stewart's bacterial wilt and wheat streak mosaic virus. Ill. Agric. Exp. Stn. Dixon Springs Agric. Cent. 5:25-43.

10. Michener, P. M., and Pataky, J. K. 2001. Relationships between incidence of systemic infection and reactions of sweet corn hybrids to Stewart's wilt. Pages 75-78 in: 2001 MWFPA Processing Crops Manual and Proceedings. Midwest Food Processors Association, Madison, WI.

11. Pataky, J. K. 2000. Reactions of sweet corn hybrids to prevalent diseases. Pages 177-192 in: Midwest Vegetable Variety Trial Report for 2000. Purdue University AES Bull. No. 798.

12. Pataky, J. K., du Toit, L. J., Kunkel, T. E., and Schmitt, R. A. 1995. Severe Stewart's wilt in central Illinois on sweet corn hybrids moderately resistant to Erwinia stewartii. Plant Dis. 80:104.

13. Pataky, J. K., Headrick, J. M., and Suparyono. 1988. Classification of sweet corn hybrid re- 
actions to common rust, northern leaf blight, Stewart's wilt, and Goss' wilt and associated yield reductions. Phytopathology 78:172-178.

14. Pataky, J. K., Michener, P. M., Freeman, N. D., Weinzierl, R. A., and Teyker, R. H. 2000. Control of Stewart's wilt in sweet corn with seed treatment insecticides. Plant Dis. 84:1104-1108.

15. Pataky, J. K., Suparyono, Hawk, J. A., Gar- diner, M. L., and Pauly, M. H. 1990. Associations between Stewart's wilt ratings and maturity of sweet corn hybrids. Plant Dis. 74:792-796.

16. Pepper, E. H. 1967. Stewart's bacterial wilt of corn. Am. Phytopathol. Soc. Monogr. No. 4.

17. Poos, F. W., and Elliott, C. 1936. Certain insect vectors of Aplanobacter stewartii. J. Agric. Res. 52:585-608.
18. Suparyono and Pataky, J. K. 1989. Influence of host resistance and growth stage at the time of inoculation on Stewart's wilt and Goss's wilt development and sweet corn hybrid yield. Plant Dis. 73:339-345.

19. Suparyono and Pataky, J. K. 1989. Relationships between incidence and severity of Stewart's and Goss's bacterial wilts and yield of sweet corn hybrids. Crop Prot. 8:363-368. 